Relations industrielles

Industrial Relations

\title{
Revised Profit Sharing Manual, Council of Profit Sharing Industries, First National Tower, Akron 8. Ohio. 1 vol. 317 pages, 1951.
}

\section{Gérard Dion}

Volume 8, numéro 1, décembre 1952

URI : https://id.erudit.org/iderudit/1023024ar

DOI : https://doi.org/10.7202/1023024ar

Aller au sommaire du numéro

\section{Éditeur(s)}

Département des relations industrielles de l’Université Laval

ISSN

0034-379X (imprimé)

1703-8138 (numérique)

Découvrir la revue

Citer ce compte rendu

Dion, G. (1952). Compte rendu de [Revised Profit Sharing Manual, Council of Profit Sharing Industries, First National Tower, Akron 8. Ohio. 1 vol. 317 pages, 1951.] Relations industrielles / Industrial Relations, 8(1), 162-163.

https://doi.org/10.7202/1023024ar

Tous droits réservés (C Département des relations industrielles de l’Université Laval, 1952
Ce document est protégé par la loi sur le droit d'auteur. L'utilisation des services d'Érudit (y compris la reproduction) est assujettie à sa politique d'utilisation que vous pouvez consulter en ligne.

https://apropos.erudit.org/fr/usagers/politique-dutilisation/ 
increase the efficiency of labor;

5) shorier hours create more jobs and expand employment.

Besides the bargaining power of the unions, other factors were responsible for shortened working time, factors such as the influence of public opinion, the gradual development of legislative protection and support, and the working of competition.

In a third section is analyzed the effect of changes in hours of work on output efficiency, absenteeism, work injuries. But how short can the workday be?

Mr. Goldner exposes the various Government Regulations on hours of work and some special collective bargaining provisions for hours of works. Related to these provisions, the overtime pay provision is studied in a following chapter.

The author makes some interesting concluding remarks and gives a few suggestions for further reading on the subject of hours of work.

F. T.

\section{Employers' Associations and Collective} Bargaining in New York City, by Jesse Thomas Carpenter; Cornell University Press, Ithaca, New York, 1950, $440 \mathrm{pp}$.

This study by Mr. Carpenter required a tremendous amount of research. It explains "how small-scale businessmen... have formed associations for the purpose of negotiating and administering labor agreements with unions of their employees". It tells why the employer bargaining groups are created, "what forms they take, what powers they exercise, and what procedures they follow". Mr. Carpenter sets forth the major patterns of multiple-employer bargaining and unfolds the various strategies, techniques and pressures that unions and associations exert upon each during the negotiation of group contracts. The Author finally follows the agreement through the many problems that arise during its administration: uniform interpretation, machinery for settling disputes, penalties and punishments upon violators.

The title of this masterly survey could be somewhat misleading. Truly, the Author deals - and generously so - with situations sorted out of the Great City's mass of cases in point. But the book carries more than a local interest. In a manner as "objective" as the subjectmatter will allow, in a fine and simple language, Mr. Carpenter describes and analyses all the intricacies of unionmanagement relations, more specifically in the field of collective bargaining.

Here is, in short, a book worthy of careful and widespread reading.

\section{R. C.}

Revised Profit Sharing Manual, Council of Profit Sharing Industries, First National Tower, Akron 8, Ohio. 1 vol. 317 pages, 1951.

Profit sharing by workers in the United States is far greater than realized. In 1943, its devotees counted some 728 companies; in 1951 there were 12,000 . They increased at the rate of about 100 a month. In 1947, a few companies who had profit sharing plans formed an association to better spread this formula. After four years it has over 300 member companies, representing $350,000 \mathrm{em}$ ployees who shared in profits. In 1948, it published the Profit Sharing Manual. After two editions, it was decided to revise it by eliminating some of the more lengthy passages, bv making certain points clearer and by adding some useful information.

Revised Profit Sharing Manual is divided into three parts, a long introduction of fifty pages, a digest of more than 90 individual plans in force at present and an appendix showing sample contracts of typical profit sharing plans, the membership list of Council of Profit Sharing Industries and a bibliography.

This book does not pretend to be a scientific work but the distinguished collaborators who have taken part in its prepara'ion, wished to present a useful, clear and practical study of the profit sharing formula. In the long introduction, they look at the problem from all angles not neglecting the theoretical and practical objections that could be invoked nor that which experience has taught. The Canadian reader will note that the legal aspects of this formula in our country is covered. In the digest of profit sharing plans, the repetitions that were to be found in Profit Sharing Manual have been avoided; 
only the sample plans were kept, giving details such as the name of the company, the number of employees concerned, the existence or not of a union, etc. This digest illustrates well that the profit sharing plan can be applied to any kind of business.

The Council of Profit Sharing Industries must be congratulated on publishing this work which will surely interest those businesses who want to get away from beaten paths and find ways to make our economy more human and more democratic.

G. D.

\section{"Progress-Sharing" can mean Industrial Peace.}

An article published in the "Reader's Digest" of September, 1952 and written by Charles E. Wilson, President of General Motors Corp. has particularly attracted our attention.

The Author presents quite briefly but in a very instructive way, the new collective agreement formula agreed upon between the Company of which he is the president, and its employees' union.

This formula has several interesting points, among others, it provides that the contract will run for five years and fixes in advance a method of adjusting and increasing wages during the course of the agreement, all based on scientifically interpreted official statistics.

The Author also makes some interesting comments in regard to the influence of the variation in wages and prices on inflation. These considerations are based on statistics covering a period of thirty years in the economic life of the United States.

He claims that increases in workers' wages do not cause inflation, but try to follow previous increases in prices, which are often caused by political decisions.

J. H. G.

(Reader's Digest, September, 1952,

Canadian Edition, pages 81 to 85 .)

\section{LIVRES REÇUS}

Chamberlain, Neil W., Collective Bargaining, 494 pp., published by McGrawHill Book Company Inc., N.Y., Toronto, London, 1951.

Ginzberg, Eli, The Labor Leader, 190 pp. published by the MacMillan Company, New York, 1948.

Melnyk, Myroslaw, Les ouvtiers étrangers en Belgique, 183 pp., publié par Institut des recherches économiques et sociales de l'Université de Louvain," Place Monseigneur Ladeuze, Louvain 1951.

Ripert, G., Le droit privé francais au milieu du XXe siècle, Pichon et Durand Paris 1950, 2 vol.

Rose, A.M., Union Solidarity, 209 pp., published by the University of Minnesota Press, Minneapolis, U.S.A., LondonGeoffrey Cumberlege, Oxford University Press, 1952.

Toubeau, R., Responsabilités actuelles des chefs d'entreprise, 114 pp., Editions Universitaires, Paris, 1952 .

Industrial Relations Research Association, Interpreting the Labor Movement, Park and University, Temp. 3, Room 5, Madison 5, Wisconsin, December 1952, 207 pages. 